\title{
Derrida after the End of Writing
}




\section{Series Board}

James Bernauer

Drucilla Cornell

Thomas R. Flynn

Kevin Hart

Richard Kearney

Jean-Luc Marion

Adriaan Peperzak

Thomas Sheehan

Hent de Vries

Merold Westphal

Michael Zimmerman 
John D. Caputo, series editor

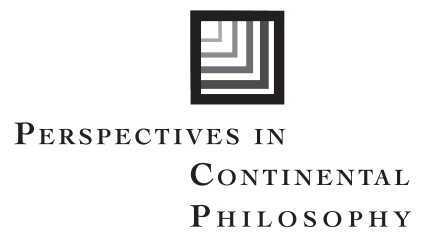





\section{CLAYTON CROCKETT}

\section{Derrida after the End of Writing Political Theology and New Materialism}




\section{Copyright (C) 2018 Fordham University Press}

All rights reserved. No part of this publication may be reproduced, stored in a retrieval system, or transmitted in any form or by any means-electronic, mechanical, photocopy, recording, or any other-except for brief quotations in printed reviews, without the prior permission of the publisher.

Fordham University Press has no responsibility for the persistence or accuracy of URLs for external or third-party Internet websites referred to in this publication and does not guarantee that any content on such websites is, or will remain, accurate or appropriate.

Fordham University Press also publishes its books in a variety of electronic formats. Some content that appears in print may not be available in electronic books.

Visit us online at www.fordhampress.com.

Library of Congress Cataloging-in-Publication Data

Names: Crockett, Clayton, 1969- author.

Title: Derrida after the end of writing : political theology and new materialism / Clayton Crockett.

Description: First edition. | New York, NY : Fordham University Press, 2017. |

Series: Perspectives in Continental philosophy | Includes bibliographical references and index.

Identifiers: LCCN 2017003972 | ISBN 9780823277834 (cloth : alk. paper) | ISBN 9780823277841 (pbk. : alk. paper)

Subjects: LCSH: Derrida, Jacques. | Religion. | Political science-Philosophy.

Classification: LCC B2430.D484 C76 2017 | DDC 194-dc23

LC record available at https://lccn.loc.gov/2017003972

Printed in the United States of America

$\begin{array}{llllllll}20 & 19 & 18 & 5 & 4 & 3 & 2 & 1\end{array}$

First edition 
for Jack, for Jacques and Everything After 
